\title{
СИНДРОМ ПРОФЕСІЙНОГО ВИГОРАННЯ ЯК СКЛАДНИЙ ПСИХОФІЗІОЛОГТЧНИЙ ФЕНОМЕН
}

\author{
В. П. Булах \\ Долинська районна лікарня, Кіровоградська область
}

У статті проаналізовано синдром професійного вигорання, його сутність, прояви, фізіологічні, психологічні, особистісні та медичні наслідки на організм людинп; деталњно розглянута його клінічна структура та динаміка формування.

\section{PROFESSIONAL BURNOUT SYNDROME AS A COMPLICATED PSYCHOPHYSIOLOGICAL PHENOMENON}

\author{
V. P. Bulakh \\ Dolyna District Hospital, Kirovohrad region
}

The article analyzes occupational burnout syndrome, its essence manifestations, physiological, psychological, personal and medical consequences on a human organism; also gives the detailed consideration to its clinical structure and its dynamics of formation.

Вступ. Синдром емоційного вигорання медичних працівників $\epsilon$ формою професійної хвороби, яка не тільки назавжди руйнує професійну діяльність людини, а й сприяє розвитку в неї різних психосоматичних захворювань.

Людина не може без праці. Завдяки їй вона відокремилася від світу тварин, до праці вона пристосована, праця є умовоюії існування. Мільйони людей щоденно йдуть працювати. Але одні йдуть через необхідність, другі - через звичку, треті ж - не можуть дочекатися, поки знову візьмуться до своєї роботи.

Медична галузь є однією з найпоширеніших сфер трудової діяльності людини. За даними ВоОз, у системі охорони здоров'я України зайнято понад 143 тис. лікарів, понад 388 тис. сестринського та акушерського персоналу. Середня ж тривалість життя лікаря, за світовою статистикою, становить усього лише 54 роки [1]. Прийнято вважати, що однією з основних причин ранньої смертності медичних працівників є синдром професійного вигорання спустошення, що формується на фоніпостійного стресу, викликаного тривалим впливом організаційних, ситуаційних факторів професійного генезу середньої інтенсивності [2].

(.) В. П. Булах, 2015
Кожен медичний працівник розуміє, що його призначення - стати майстром своєї справи, досвідченим фахівцем. На жаль, майстерності досягають далеко не всі медики. Існує низка причин, які не тільки не дають лікарю чи медичній сестрі досягти високого рівня майстерності, а і здатні призвести їх до професіональної кризи, соціальної деградації, повного психоемоційного спустошення.

Основна частина. В останні чотири десятиріччя у світовій науковій літературі жваво обговорюється проблема так званих burnout diseases - вигорання на робочому місці, які охоплюють психологічні, психічні та фізичні розлади, пов'язані з впливом факторів виробничого середовища сучасного урбанізованого суспільства. Всесвітня організація охорони здоров'я назвала професійний стрес хворобою XXI століття, тому що цей вид стресу спостерігається в будь-якій професії світу досягаючи розмірів глобальної епідемії [3]. Варто наголосити, що він, навіть, був включений до Міжнародної класифікації хвороб (МКХ-10), у класифікаційну рубрику «Проблеми, пов'язані з труднощами подолання життєвих ускладнень, труднощами управління власним життям», під номером Z 73.0 [4]. Експерти зазначають, що людина, уражена синдромом, відчуває стійке небажання йти на 
роботу, що супроводжується депресією, порушенням сну, пам'яті та уваги, зниженням активності, втратою інтересу до повсякденної діяльності, відчуттям ії безглуздя, бажанням уникнути виконання своїх обов'язків. Знижується інтерес не тільки до професії, але і до самого життя в цілому.

Незважаючи на те, що в другій половині XX століття вищезгаданий синдром став об'єктом спеціального наукового вивчення, і починаючи з 1974 року було надруковано більше 2500 статей і книг на тему психоемоційного вигорання, слід зазначити, що ні одна із них так і не змогла назвати першопричину розвитку захворювання. Як у вітчизняних, так і в зарубіжних вчених, навіть, немає єдиної думки щодо сутності поняття «синдрому професійного вигоряння».

Уперше термін «вигорання» ввів до наукового обігу Г. Брендлі в своєму дослідженні службовців, які охороняли умовно засуджених. Пізніше вигорання вивчав Г. Фрейденбергер, який визначав емоційне вигорання як хронічну втому, депресію і фрустрацію, коли індивід вимушений займатися справою, яка не задовольняє його амбіції й не приносить очікуваного результату [5].

Більшість авторів розглядає феномен емоційного вигорання як фізичне, психічне або емоційне виснаження, втрату мотивації й відповідальності, а також як результат невідповідності між особистістю і родом занять. Freudenberger $\mathrm{H}$. та Richelson $\mathrm{G}$. вважають вигорання ознакою певних психологічних станів хронічної стомленості, депресії та фрустрації [6]. Hobfoll S. i Shirom А. відокремили від хронічного стомлення синдром хронічної втоми (СХВ), який пов'язаний з дисбалансом між вимогами навколишнього середовища та здатністю людини виконувати ці вимоги. Вони підкреслювали, що основою механізмів розвитку саме синдрому вигорання $\epsilon$, перш за все, емоційне (потім фізичне та когнітивне) виснаження [7]. Водоп'янова Н. С. та Старченкова $Є$. С. називають це синдромом психічного вигорання, а Сидоров П. синдромом емоційного вигорання $[8,9]$. Підсумовуючи викладене, можна зазначити, що незважаючи на відмінність у підходах різних авторів до його визначення, синдром вигорання є особистісною деформацією внаслідок емоційно ускладнених або напружених відносин у системі «людина-людина».

Згідно з точкою зору більшості дослідників, такі поняття як «втома», «стрес», «нервове виснаження», «професійна деформація», «професійне вигорання» $\epsilon$ хоч і спорідненими, але відносно самостійними феноменами. Звідси випливає, що потрібно чітко відрізняти поняття «професійне вигорання» від вищеперерахованих суміжних понять.

основна відмінність між вигоранням і втомою полягає у тому, що в останньому випадку людина здатна швидко відновитись, а в першому - ні.

Перша відмінність між стресом і вигоранням приховується, перш за все, в тривалості процесу: вигорання - це тривалий, «розтягнений» у часі робочий стрес. Другою відмінністює те, що стрес це все-таки адаптивний синдром, який мобілізує всі сторони психіки людини, а вигорання - це зрив в адаптації. Третьою відмінністю між стресом і вигоранням є ступінь їх розповсюдження. Стрес може відчувати кожен, а вигорання проявляється тільки в професійній діяльності. Четвертою відмінністю $\epsilon$ те, що стрес не обов'язково може бути причиною вигорання. Відомо, що люди здатні прекрасно працювати в стресових умовах (наприклад, під час війни, стихійних лих, епідемій), якщо вважають, що їхня робота $\epsilon$ важливою та значущою. І останньою відмінністю $є$ те, що вигорання на відміну від стресу $\epsilon$ феноменом незворотним: виникнувши в людини, він продовжує розвиватись, і можна тільки певним чином загальмувати цей процес.

Нервове виснаження - це синдром фізичного, розумового та душевного виснаження, що характеризується прогресивною втратою ідеалів і мети. Більше схильні до нервового виснаження люди, про яких кажуть, що вони одержимі роботою, ідеалісти, надзвичайно пунктуальні та відповідальні, які прагнуть будь-що досягти високих результатів, або надто віддані своїй справі [10]. Симптоми, які виникають внаслідок стресу, слід відрізняти від нервового виснаження, яке $\epsilon$ значно тяжчим станом і може виникнути в результаті постійної та наростаючої стресової ситуації (рис. 1).

Професійна «деформація» медичного працівника розвивається поступово, починаючи з його професійної адаптації. Однією з перших ознак такої адаптації стає зниження емоційного сприймання і реагування на страждання та смерть іншої людини. Не менш важлива "деформація" фахівця виникає внаслідок соціальних причин, адже робота лікаря, медичної сестри пов'язана з необхідністю дотримання численних норм, правил та інструкцій, що регламентують його фахову діяльність. Намагання чітко дотримуватися вимог інструкцій, які не завжди відповідають, а часто навіть суперечать знанням і досвіду медичних праців- 


\section{СКМПТОМИ, ЯКІ IРОЯВНЯЮТЬСЯ В РАЗГ СТРЕСУ 1 HEPВOВОГО ВНСНАЖЕННЯ}

\author{
Cmpec: \\ - тphaori \\ - незндоволення \\ - прнтуллени поңуття \\ в ілданості poбoti \\ - 3rifa has rporo \\ - відчутन проншви \\ - Heygarejicth \\ - piзjororít зmizk
}

Hepsoве виснаженті:

* хронічна втомленість

- пезадоволена потре6а

ДОСЯГТИ внзнанНЯ

- нудыген

- циніза

- нетерпим јсль абор роздратуняннд

- дегресіл

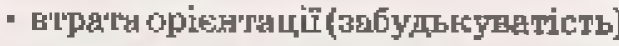

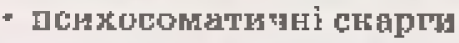

PUC. 1. Порівняльна характеристика симптомів, які проявляються в разі стресу і нервового виснаження.

ників, також сприяють виробленню формального підходу до пацієнта не як до цілісної особистості, а як до об'єКта, на певну частину якого необхідно здійснити вплив [11]. Професійна «деформація» виявляється на пізніших етапах професійної кар'єри, тоді як вигорання може виникнути і на початку професійного шляху як результат невідповідності між вимогами професії й домаганнями особистості. На відміну від професійної «деформації», психічне вигорання можна більшою мірою вважати випадком повного регресу професійного розвитку, оскільки воно зачіпає особистість в цілому, руйнує ї̈ та має негативний вплив на ефективність трудової діяльності [12].

Вигорання $\epsilon$ результатом складного балансу чинників і $є$ наддетермінованим. Це означає, що безліч стресорів безперервно підсумовуються в різних сферах життєдіяльності і якщо особа може реагувати на це адаптивно, вона діє успішно і ефективно. Якщо ж зовнішні вимоги починають переважати над ресурсами людини, виникає дезадаптація, яка з часом закріплюється і призводить до вигорання.

Більшість дослідників виділяє три види чинників: особистісний (вік, стать, стаж роботи, сімейний стан, неврівноваженість, підвищена збудливість, емоційна нестійкість індивіда, відповідність його темпераменту роботі, спрямованість до екстра- чи інтравертованості), рольовий (різні професійні ситуації, у яких спільні дії співробітників неузгоджені), та організаційний (дестабілізуюча організація роботи, підвищений рівень відповідальності, складний психологічний контингент пацієнтів: психічно хворі, онкохворі, пацієнти з алкогольною та наркотичною залежністю), які впливають на формування вигорання. Деякі дослідники вважають, що особові особливості впливають на розвиток вигорання набагато більше, ніж демографічні характеристики і чинники робочого середовища.

Деякі дослідники вважають відсутність професіональної мотивації основною передумовою розвитку професійного вигорання. Наприклад, дослідження І. В. Тарасової показало, що без професійної мотивації свою професійну діяльність почали 25 \% медсестер [13].

Синдром вигорання має досить складну структуру. Даний синдром включає три основні складові: емоційну виснаженість, деперсоналізацію (цинізм) і редукцію професійних досягнень. Під емоційним виснаженням розуміється відчуття емоційної спустошеності і втоми, викликане власною роботою. Деперсоналізація припускає цинічне ставлення до праці і об'єКтів своєї праці. Зокрема, в медицині деперсоналізація припускає бездушне, негуманне ставлення до пацієнтів, які приходять для лікування, консультації тощо. Пацієнти сприймаються не як живі люди, а всі їх проблеми і біди, з якими вони приходять до лікаря, із його точки зору, ємалозначимі [14]. Емоційно виснажені медичні працівники майже повністю виключають емоції з сфери професійної діяльності. їх майже нічого не хвилює, майже ніщо не викликає емоційного відгуку - ні позитивні обставини, ні негативні. Причому це не вихідний дефект емоційної сфери, не ознака ригідності, а набутий за роки професійної діяльності емоційний захист.

Нарешті редукція професійних досягнень - виникнення у працівників відчуття некомпетентності в своїй професійній сфері, усвідомлення неуспіху в ній [15]. Зникає потяг до фахового та особистісного вдосконалення, з'являється схильність до прийняття традиційних форм знання, шаблонних дій, ригідність операцій мислення. В результаті формується стійке не- 
гативне ставлення до самого себе, відчуття провини, що призводить до підвищеної тривожності, песимістичної налаштованості і репресивності [16].

Перелік психологічних симптомів, які є складовими відповідних фаз синдрому вигорання, наведено у таблиці 1. Ці симптоми певною мірою відображають психоемоційний стан людини, а також стан його соматичного здоров'я.

Суб'єктивно синдром характеризується депресивним станом, відчуттям втоми і спустошеності, зменшенням енергії та ентузіазму, втратою здатності бачити позитивні результати своєї праці, негативною установкою щодо роботи і життя, соматичними захворюваннями.

На думку К. Маслач, психокорекція синдрому професійного вигорання ефективна тільки на перших двох стадіях. Після переходу розвитку синдрому на третю стадію, вигорання усувається тільки за допомогою тривалої глибинної психотерапії [15]. Згідно з поглядами вітчизняних дослідників, перерви в роботі дають позитивний ефект і знижують рівень вигорання, але цей ефект має тимчасовий характер: рівень вигорання підвищується вже через 3 дні після повернення до роботи і повністю відновлюється через 3 тижні [16].

Таблиця 1. Групи симптомів, характерних для синдрому професійного вигорання

\begin{tabular}{|c|c|}
\hline $\begin{array}{c}\text { Найменування } \\
\text { ключової групи ознак }\end{array}$ & Симптоматика \\
\hline $\begin{array}{l}\text { Група фізичних } \\
\text { симптомів }\end{array}$ & $\begin{array}{l}\text { стомленість, фізична втома, виснаження; зміна маси тіла (схуднення або збільшення маси тіла); } \\
\text { недостатній сон, безсоння; незадовільний загальний стан здоров'я; тяжке дихання, задишка; } \\
\text { нудота, запаморочення, надмірна пітливість, тремтіння тіла; артеріальна гіпертензія; виразки і } \\
\text { запалення на шкірі та слизових оболонках, патологічні прояви хвороб серця та судин }\end{array}$ \\
\hline $\begin{array}{l}\text { Група емоційних } \\
\text { симптомів }\end{array}$ & $\begin{array}{l}\text { нестача емоцій; песимізм, цинізм і черствість у роботі та особистому житті; байдужість, } \\
\text { втома; відчуття безпорадності та безнадійності; агресивність, дратівливість; тривога, } \\
\text { посилення ірраціонального неспокою; нездатність зосередитися; депресія, відчуття провини; } \\
\text { істерики, душевні страждання; втрата ідеалів, надії або професійних перспектив; збільшення } \\
\text { деперсоналізації своєї чи інших: люди стають безликими, як манекени; переважає відчуття } \\
\text { самотності }\end{array}$ \\
\hline $\begin{array}{l}\text { Група інтелектуальних } \\
\text { симптомів }\end{array}$ & $\begin{array}{l}\text { зниження інтересу до нових теорій та ідей у роботі, до альтернативних підходів у вирішенні } \\
\text { проблем; нудьга, туга, апатія; втрата смаку та інтересу до життя; надання переваги стандартним } \\
\text { шаблонам, схемам, рутині, ніж креативно-творчому підходу; цинізм і байдужість до новин; } \\
\text { недостатня участь чи відмова від участі у творчих експериментах - тренінгах, курсах; формалізм у } \\
\text { виконанні роботи }\end{array}$ \\
\hline $\begin{array}{l}\text { Група поведінкових } \\
\text { симптомів }\end{array}$ & $\begin{array}{l}\text { робочий час - понад } 45 \text { годин на тиждень; під час роботи з'являються втома і бажання відпочити; } \\
\text { байдужість до їжі; недостатнє фізичне навантаження; виправдання вживання тютюну, алкоголю, } \\
\text { ліків; нещасні випадки - падіння, травми, аварії тощо, імпульсивна емоційна поведінка }\end{array}$ \\
\hline $\begin{array}{l}\text { Група соціальних } \\
\text { симптомів }\end{array}$ & $\begin{array}{l}\text { низька соціальна активність; зниження інтересу до дозвілля, захоплень; соціальні контакти } \\
\text { обмежуються роботою; байдужість у ставленні до співробітників та рідних; відчуття ізоляції, } \\
\text { непорозуміння з іншими; відчуття нестачі підтримки з боку сім'ї, родичів, друзів і колег }\end{array}$ \\
\hline
\end{tabular}

Висновок. За переконаннями більшості науковців, вигорання $є$ феноменом незворотним: виникнувши в людини, воно продовжує постійно розвиватись, і можна тільки тимчасово загальмувати цей процес.
Синдром професійного вигорання не залежить ні від віку, ні від статі медпрацівників, ні від умов організації медичної діяльності. Але його можна уникнути, якщо 3 любов'ю ставитися до своєї професії, до пацієнтів.

\section{ЛITEPATУРA}

1. Гігієна праці : підручник / [Ю.І.Кундієва, О. П. Яворовського, А. М. Шевченко та ін.]. - К. : ВСВ «Медицина», 2011.-904c.

2. Скутаревская М. М. Синдром эмоционального выгорания / М. М. Скутаревская // Мед. новости. - 2002. № 7. - C. 3-9.
3. World Health Organization. The ICD-10 Classification of Mental and Behavioral Disorders: clinical descriptions and diagnostic guidelines. - Geneva: WHO, 1992.

4. Манн Т. Будденброки. История гибели одного семейства / Т. Манн. - М. : Международные отношения. $-1982 .-496$ c. 
5. Сидоров П. Синдром эмоционального «выгорания» / П. Сидоров // Новости медицины и фармации. - 2005. № 13. - C.7-8.

6. Матвієнко О. Культура здоров'я персоналу та синдром психоемоційного «вигорання»: стратегія і тактика подолання / О. Матвієнко, М. Пересадін, $\epsilon$. Андросов // Головна медична сестра. - 2007. - № 6. - С. 20-23.

7. Акарачкова Е. С. Хронический стресс и нарушение профессиональной адаптации / Е. С. Акарачкова // Журнал неврологии и психиатрии. - 2011. - № 5. - С. 56-59.

8. Гридчик И. Е. Синдром профессионального выгорания медицинского персонала в отделениях анестезиологии и реанимации / И. Е. Гридчик // Анестезиология и реаниматология. - 2009. - № 3. - С. 9-13.

9. Касевич Н. К. Охорона праці та безпекажиттєдіяльності медичних працівників : підручник / Н. К. Касевич, К. І. Шаповал. - К. : ВСВ «Медицина», 2010. - 248 с.

10. Тарасова И. В. Профессиональный стресс / И. В. Тарасова // Сестринское дело, - 2005. - № 2. - С. 22-24.
11. Синдром професійного вигорання в сімейній медицині: шляхи діагностики та профілактики / [М. М. Островський, М. В. Франко, 3. Й. Остальська та ін.] // Практична медицина. - 2008. - № 4. - С. 13-18.

12. Дмитренко Г. Культура здоровья в системе управления человеческими ресурсами / Г. Дмитренко, В. Пономаренко // Персонал. - 2003. - № 1. - С. 78-82.

13. Пишнов Г. Ю. Особливості структури взаємозв'язку психофізіологічних характеристик у осіб напруженої праці з різним рівнем хронічного стомлення / Г. Ю. Пишнов, В. В. Кальниш // Журнал НАМН України. - 2011. Т. 17, № 3. - С. 270-280.

14. Бойко В. В. Энергия эмоций в общении: взгляд на себя и других / В. В. Бойко. - М. : Филинь, 1996. -472 с.

15. Maslach C. Prevention of burnout: new perspectives / C. Maslach, J. Goldberg //Applied and Preventive Psychology.1998. - Vol. 7. - P. 63-74.

16. Культура здоров'я особистості : курс лекцій / [І. О. Олеандер, В. С. Грушко, Т. І. Бережна та ін.]. Тернопіль : Навчальна книга - Богдан, 2010. - 196 с.

Отримано 30.10 .15 